Berichte der Bunsen-Gesellschaft für physikalische Chemie (früher Zeitschrift für Elektrochemie)

(C) Verlag Chemie GmbH, D-6940 Weinheim 1979 - Printed in Germany 


\title{
Trans/Cis Photoisomerization of 4-Stilbenecarboxylate Coordinated to Rhodium(III) and Iridium(III)
}

\author{
Arnd Vogler and Alfred Kern \\ Universität Regensburg, Institut für Chemie, D-8400 Regensburg
}

\begin{abstract}
Absorptionsspektren, sichtbar und ultraviolett / Fluoreszenz / Komplexverbindungen / Photochemie
The electronic absorption spectra of trans-4-stilbenecarboxylic acid HTSC, its sodium salt $\mathrm{NaTSC},\left[\mathrm{Rh}\left(\mathrm{NH}_{3}\right)_{5} \mathrm{TSC}^{2+}\right.$, and $\left[\operatorname{Ir}\left(\mathrm{NH}_{3}\right)_{5} \mathrm{TSC}\right]^{2+}$, dissolved in different solvents, all show a nearly identical long wavelength absorption band at $319 \mathrm{~nm}$. This band is assigned to the first spin-allowed $\left(\mathrm{S}_{0} \rightarrow \mathrm{S}_{1}\right) \pi \pi^{*}$ transition of $\mathrm{TSC}^{-}$and appears as an isolated intraligand chromophore in the complexes. Whereas HTSC and TSC $^{-}$emit a fluorescence, this emission is completely quenched in the complexes. Not only HTSC, but also $\left[\mathrm{Rh}\left(\mathrm{NH}_{3}\right)_{5} \mathrm{TSC}\right]^{2+}$, and $\left[\operatorname{Ir}\left(\mathrm{NH}_{3}\right)_{5} \mathrm{TSC}\right]^{2+}$ undergo trans/cis photoisomerization of the stilbene moiety upon $\mathrm{S}_{0} \rightarrow \mathrm{S}_{1}$ intraligand excitation. While the $\mathrm{S}_{1}$ state of the free ligand is assumed to initiate the isomerization, the results support the first triplet $\left(\mathrm{T}_{1}\right)$ of the coordinated $\mathrm{TSC}^{-}$as the photoactive excited state. In the complexes, the heavy metals seem to induce $\mathrm{S}_{1} \rightarrow \mathrm{T}_{1}$ intersystem crossing.
\end{abstract}

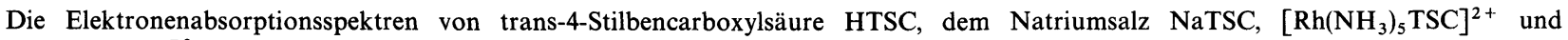
$\left[\operatorname{Ir}\left(\mathrm{NH}_{3}\right)_{5} \mathrm{TSC}\right]^{2+}$, gelöst in verschiedenen Lösungsmitteln, enthalten alle eine nahezu identische Absorptionsbande im Langwelligen bei $319 \mathrm{~nm}$. Diese Bande wird dem ersten spinerlaubten $\left(\mathrm{S}_{0} \rightarrow \mathrm{S}_{1}\right) \pi \pi^{*}$-Übergang von $\mathrm{TSC}^{-}$zugeordnet und tritt in den Komplexen als isolierter Intraligandenchromophor auf. Während HTSC und TSC $^{-}$fluoreszieren, ist diese Emission in den Komplexen völlig gelöscht. Nicht nurHTSC, sondern auch $\left[\mathrm{Rh}\left(\mathrm{NH}_{3}\right)_{5} \mathrm{TSC}\right]^{2+}$ und $\left[\mathrm{Ir}\left(\mathrm{NH}_{3}\right)_{5} \mathrm{TSC}\right]^{2+}$ unterliegen einer trans/cis-Photoisomerisierung der Stilbenkomponente als Folge der $S_{0} \rightarrow S_{\overline{1}}$ Intraligandenanregung. Während der $S_{1}$-Zustand die Isomerisierung des freien Liganden auslöst, ist im koordinierten Ligand offensichtlich das niedrigste Triplett $\left(T_{1}\right)$ photoaktiv. Es wird angenommen, daß die Schwermetalle in den Komplexen das Intersystem-crossing von $S_{1}$ nach $T_{1}$ induzieren.

\section{Introduction}

Whereas photochemical reactions of transition metal complexes originating from excited ligand field (LF) and charge transfer (CT) states have been extensively investigated, the reactivity of intraligand (IL) states has not been studied to the same extent $[1,2]$. For simple ligands such as $\mathrm{NH}_{3}$ or $\mathrm{CN}^{-}$, IL states are either experimentally not accessible $\left(\mathrm{NH}_{3}\right)$ or at very high energies $\left(\mathrm{CN}^{-}\right)$. In the latter case they are in an energy region where there is an accumulation of excited states of different origin and hence any correlation between observed photochemical reaction and the nature of the reactive excited state is difficult to establish. In other cases where IL transitions are at reasonably low energies, the electronic structure of the ligands is often very much changed by the interaction with the metal. IL states are then heavily mixed with other excited states, particularly with CT states [2]. The change of intensity and energy of IL absorption bands which occurs upon coordination of the free ligand is a good indication that this mixing is occurring. It is again difficult to establish a clear relationship between a photochemical reaction of the coordinated ligand and the nature of the reactive excited state. These complications occur for the complexes $\mathrm{W}(\mathrm{CO})_{5}$ (styrylpyridine) [3], $\mathrm{Re}(\mathrm{CO})_{3}$ (styrylpyridine) ${ }_{2} \mathrm{Cl}[4],[\mathrm{Ru}(\mathrm{bi}-$ pyr)(trans-4-styrylpyridine) $\left.{ }_{2}\right]^{2+}[5]$, and $\mathrm{M}(\mathrm{CO})_{5}$ stilbene [6] $(\mathbf{M}=$ Mo and $\mathbf{W})$, which have been shown to undergo trans/ cis photoisomerization of the stilbene or stilbene derivatives as ligands showing essentially the same photochemical behavior as the free ligands. However, in these cases the metal can interact directly with the $\pi$-electron system of the ligands and modify their electronic structure $[2,4]$. In addition, low 
energy CT transitions from the metal to the stilbene ligands are possible. The shift of the IL-bands which occurs upon coordination may then be caused also by CT contributions [2]. Since these CT states might also be able to initiate trans/ cis isomerizations [2], the nature of the reactive excited states of these complexes is not clearly known.

To avoid these complications, trans-4-stilbene carboxylate $\left(\mathrm{TSC}^{-}\right)$has been chosen as a ligand. When it coordinates via the carboxylic group, the $\pi$-electron system of stilbene is not directly affected by the metal leaving the ligand as an isolated chromophore. This has been demonstrated for the complex $\left[\mathrm{Co}\left(\mathrm{NH}_{3}\right)_{5} \mathrm{TSC}\right]^{2+}[7]$. However, IL excitation does not lead to the expected isomerization of the ligand but to a redox reaction involving cobalt as well as the $\mathrm{TSC}^{-}$ligand.

For the present study Co(III) was replaced by the homologous $\mathrm{Rh}(\mathrm{III})$ and $\mathrm{Ir}(\mathrm{III})$ which are rather redox inert. The complexes $\left[\mathrm{M}\left(\mathrm{NH}_{3}\right)_{5} \mathrm{TSC}\right]^{2+}(\mathrm{M}=\mathrm{Rh}$ and $\mathrm{Ir})$ are expected to be suitable examples to study the photoreactivity of pure IL excited states. Acidopentaammines of Rh(III) and Ir(III) are kinetically stable. In addition, the photochemistry of rhodium complexes of this type has been investigated to a great extent [8].

Although the basic photoreaction of stilbenes is simply the trans/cis isomerization, the sequence of photophysical and photochemical steps following light absorption seems to be a complicated process [9]. The present investigation was also done with hopes of providing additional information on the photochemistry of stilbenes.

\section{Experimental Section}

\section{Materials}

trans-4-stilbenecarboxylic acid (HTSC) [10], cis-4-stilbenecarboxylic acid (HCSC) [11], and $\left[\mathrm{Rh}\left(\mathrm{NH}_{3}\right)_{5}\right.$ acetato $\left(\mathrm{ClO}_{4}\right)_{2}$ [12] were prepared according to published procedures. Their UV spectra agreed well with those reported. $\left[\mathrm{Rh}\left(\mathrm{NH}_{3}\right)_{5} \mathrm{TSC}\right]\left(\mathrm{ClO}_{4}\right)_{2}$ and $\left[\operatorname{Ir}\left(\mathrm{NH}_{3}\right)_{5} \mathrm{TSC}\right]\left(\mathrm{ClO}_{4}\right)_{2}$ were synthesized by the same procedure which has been used for the preparation of $\left[\mathrm{Co}\left(\mathrm{NH}_{3}\right)_{5} \mathrm{TSC}\right]\left(\mathrm{ClO}_{4}\right)_{2}$ [7].

Anal. Calcd. for $\left[\mathrm{Rh}\left(\mathrm{NH}_{3}\right)_{5} \mathrm{O}_{2} \mathrm{C}_{15} \mathrm{H}_{11}\right]\left(\mathrm{ClO}_{4}\right)_{2}$ :

C $29.51 ; \mathrm{H} 4.29 ; \mathrm{N} 11.47$. Found: C 29.52; H 4.52; N 11.00 .

Anal. Calcd. for $\left[\mathrm{Ir}\left(\mathrm{NH}_{3}\right)_{5} \mathrm{O}_{2} \mathrm{C}_{15} \mathrm{H}_{11}\right]\left(\mathrm{ClO}_{4}\right)_{2}$ :

C 25.75 ; H 3.75; N 10.13. Found: C 25.05; H 3.85; N 9.84 .

\section{Photolysis Procedures}

The light surces used were a $100 \mathrm{~W}$ high-pressure mercury lamp Osram HBO 100 and a $450 \mathrm{~W}$ high-pressure xenon lamp Osram XBO 450. An interference filter was used to select the $313 \mathrm{~nm}$ line. Two Schott cut-off filters GG 495 were used to obtain wavelengths longer than $500 \mathrm{~nm}$. The photolyses were carried out in spectrophotometer cells. For quantum-yield measurements, the complex concentrations were such as to have essentially complete light absorption. The total amount of photolysis was limited to less than $5 \%$ to avoid light absorption by the photoproduct. Absorbed light intensities were determined by ferrioxalate actinometry.

\section{Neasurements}

Visible and ultraviolet spectra were measured either with a Cary 14 recording spectrophotometer or a Varian-Techtron Super Scan 3 recording spectrophotometer while a Zeiss PMQ II spectrophotometer was used for measurements at selected wavelengths.

Emission spectra were recorded on an Aminco spectrophotofluorometer.

\section{Results}

The spectrum of trans-4-stilbenecarboxylic acid (HTSC) shows two intense absorption maxima at $230 \mathrm{~nm}(\varepsilon=14470)$ and $319 \mathrm{~nm}$ $(\varepsilon=38000)$ [7]. The fluorescence maximum appears at $400 \mathrm{~nm}$ [7]. The spectra remain almost unchanged when the acid was converted to the corresponding TSC $^{-}$anion. Cis-4-stilbenecarboxylic acid (HCSC) and the corresponding carboxylate $\left(\mathrm{CSC}^{-}\right)$, which do not fluoresce, exhibit absorption maxima at $233 \mathrm{~nm}(\varepsilon=20900)$ and $292 \mathrm{~nm}(\varepsilon=13560)$ [7]. The longest wavelength maxima of HTSC and $\mathrm{HCSC}$ or $\mathrm{TSC}^{-}$and $\mathrm{CSC}^{-}$are assigned to the first spin-allowed $\left(\mathrm{S}_{0} \rightarrow \mathrm{S}_{1}\right) \pi \pi^{*}$ transition in analogy to other stilbene derivates.

The irradiation of the longest-wavelength absorption band of HTSC in ether, ethanol, methanol, dimethylformamide, or acetonitrile $\left(\lambda_{\text {irr }}=313 \mathrm{~nm}\right)$ was accompanied by spectral changes which clearly showed that a trans $\rightarrow$ cis isomerization took place. At the isosbestic point at $277 \mathrm{~nm} \mathrm{HTSC}$ and HCSC have the same extinction coefficients $(\varepsilon=11700)$. Continued photolysis led to a photostationary equilibrium between HTSC and HCSC since HCSC underwent a photoisomerization back to HTSC. After longer periods of irradiation, new spectral variations were observed indicating a further photolysis pathway.

Quantum yields for the trans to cis isomerization were determined by measuring the change of extinction at $319 \mathrm{~nm}$. From the photostationary equilibria (Table 1) and the extinction coefficients at $313 \mathrm{~nm}$ the quantum yields for the cis to trans isomerization (Table 1) $\phi_{\text {cis }}$ were calculated using the experimentally determined quantum yields of the trans to cis isomerization $\phi_{\text {trans }}$.

The absorption spectra of the complexes $\left.\left[\mathrm{M}(\mathrm{NH})_{3}\right)_{5} \mathrm{TSC}\right]^{2+}$ $(\mathrm{M}=\mathrm{Rh}$ and Ir, Fig. 1) dissolved in water, methanol, dimethylformamide, or acetonitrile are nearly identical with those of HTSC or $\mathrm{TSC}^{-}$. The longest wavelength $\mathrm{LF}$ band of $\left[\mathrm{Rh}\left(\mathrm{NH}_{3}\right)_{5} \text { acetate }\right]^{2+}$ occurs at $322 \mathrm{~nm}(\varepsilon=147)$. Since it has been shown that the ligand field strength of carboxylates $\mathrm{RCOO}^{-}$is nearly independent of the substituent $\mathrm{R}[7,12]$ the low-intensity $\mathrm{LF}$ band of $\left[\mathrm{Rh} \mathrm{NH}_{3} \mathrm{TSC}\right]^{2+}$ must be hidden under the intense IL-bands of the $\mathrm{TSC}^{-}$ligand. Since the LF splitting increases from the lighter to the heavier metals within a group, the $\mathrm{LF}$ bands of $\left[\operatorname{Ir}\left(\mathrm{NH}_{3}\right)_{5} \mathrm{TSC}\right]^{2+}$ are certainly also hidden under the IL-bands. The complexes $\left[\mathrm{M}\left(\mathrm{NH}_{3}\right)_{5} \mathrm{TSC}\right]^{2+}$ $(\mathbf{M}=\mathrm{Rh}$ and $\mathrm{Ir})$ do not show any emission at room temperature or at $77 \mathrm{~K}$. Upon irradiation of the dissolved complexes (Fig. 1)

Table 1

Quantum yields of trans/cis isomerization and photostationary equilibria of 4-stilbenecarboxylate at $313 \mathrm{~nm}$ irradiating wavelength

\begin{tabular}{c|ccc|ccc|ccc}
\hline Compound & \multicolumn{3}{|c|}{$\mathrm{HTSC}$} & \multicolumn{3}{c|}{$\left[\mathrm{Rh}\left(\mathrm{NH}_{3}\right)_{5} \mathrm{TSC}\right]^{2+}$} & \multicolumn{3}{c}{$\left[\operatorname{Ir}\left(\mathrm{NH}_{3}\right)_{5} \mathrm{TSC}^{2+}\right.$} \\
\hline Solvent & $\left.\mathrm{DMF}^{\mathrm{a}}\right)$ & $\mathrm{H}_{2} \mathrm{O}$ & $\mathrm{CH}_{3} \mathrm{CN}$ & $\mathrm{DMF}$ & $\mathrm{H}_{2} \mathrm{O}$ & $\mathrm{CH}_{3} \mathrm{CN}$ & $\left.\mathrm{DMF}^{a}\right)$ & $\mathrm{H}_{2} \mathrm{O}$ & $\mathrm{CH}_{3} \mathrm{CN}$ \\
\hline$\left.\phi_{\text {trans }}{ }^{\mathrm{b}}\right)$ & 0.26 & 0.39 & 0.40 & 0.07 & 0.09 & 0.09 & 0.17 & 0.19 & 0.25 \\
$\left.\%_{\text {cis }}{ }^{c}\right)$ & 75 & 86 & 84 & 44 & 54 & 54 & 68 & 83 & 75 \\
$\left.\phi_{\text {cis }}{ }^{d}\right)$ & 0.45 & 0.33 & 0.40 & 0.46 & 0.40 & 0.40 & 0.42 & 0.21 & 0.43 \\
\hline
\end{tabular}

a) DMF (dimethylformamide).

b) trans to cis isomerization, precision $\pm 7 \%$.

c) $\%_{\text {cis }}$ compound at the photostationary equilibrium. Since longer irradiation times cause secondary photolysis, the precision is not better than $\pm 12 \%$.

d) cis to trans isomerization, calculated from $\phi_{\text {trans }}$ and the trans : cis ratio at the photostationary equilibrium, precision $\pm 15 \%$. 


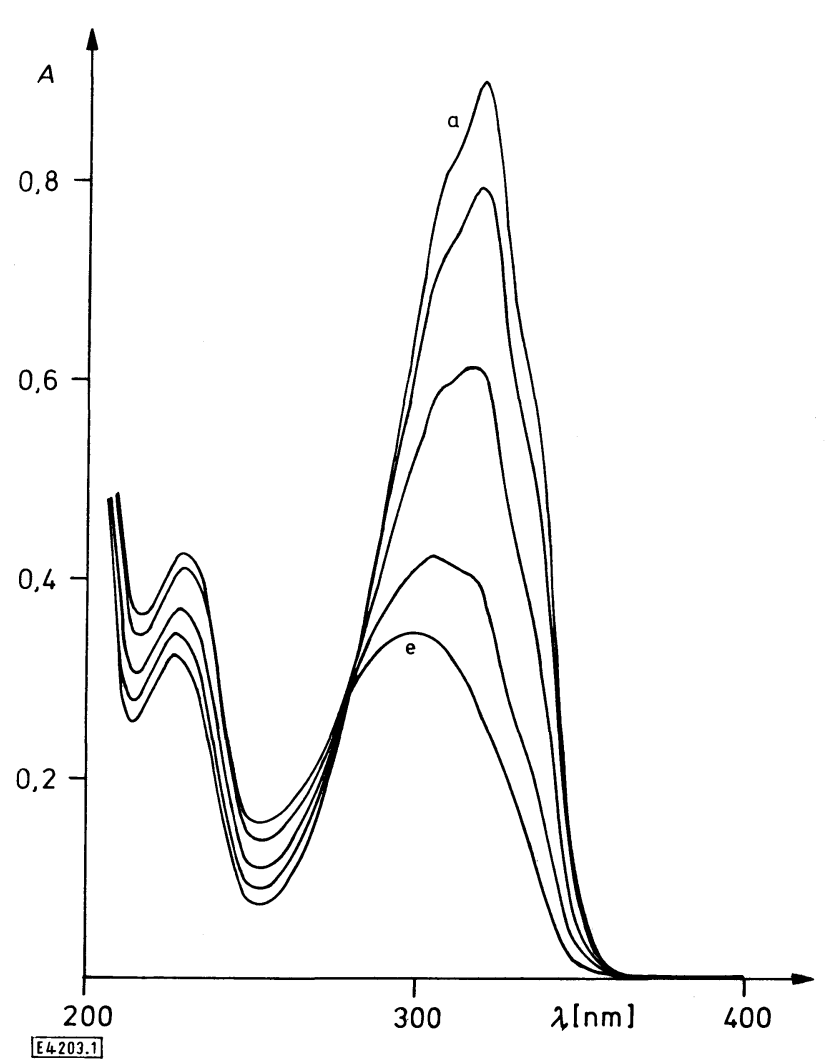

Fig. 1

Spectral changes observed upon irradiating a $2.35 \cdot 10^{-5} \mathrm{M}$ aqueous solution of $\left[\operatorname{Ir}\left(\mathrm{NH}_{3}\right)_{5} \mathrm{TSC}\right]^{2+}$ in a 1 -cm cell with $\lambda=313 \mathrm{~nm}$. Total irradiation time between (a) initial and (e) final is $25 \mathrm{~min}$.

with light at $313 \mathrm{~nm}$, the same changes occured as were observed during the photolysis of HTSC. Since the complexes also underwent only the isomerization of the $\mathrm{TSC}^{-}$ligand, the determination of quantum yields (Table 1) was done following the same procedures as were applied for the free ligand.

Only after prolonged irradiation $\left(\lambda_{\mathrm{irr}}=313 \mathrm{~nm}\right)$ of the complexes did the photolyzed solutions show a weak fluorescence of the free $\mathrm{TSC}^{-}$ligand, indicating that any photosubstitution of the $\mathrm{TSC}^{-}$ ligand occurs with very low quantum yields $\left(\phi<10^{-2}\right)$. The absence of any efficient substitution of $\mathrm{TSC}^{-}$was confirmed by the observation that the photolysis in $0.1 \mathrm{M} \mathrm{HClO}_{4}$ did not lead to a precipitation of HTSC and HCSC which are almost insoluble in acidic aqueous solution.

Since it was assumed that in the metal complexes a heavy atom effect induces intersystem crossing within the $\mathrm{TSC}^{-}$ligand, an increase of the intensity of the first spin-forbidden $\left(S_{0} \rightarrow S_{1}\right)$ absorption band was expected to occur. No such band could be identified in the long wavelength region of the spectrum of the Ir complex where the heavy atom effect should be largest because Ir is a third row transition metal. However, if some light would be absorbed by an even weak $S_{0} \rightarrow T_{1}$ band, the population of the $\mathrm{TSC}^{-}$triplet should cause an isomerization [13].

After 5 hours of irradiation $\left[\operatorname{Ir}\left(\mathrm{NH}_{3}\right)_{5} \mathrm{TSC}\right]^{2+}$ dissolved in dimethylformamide $\left(2.1 \cdot 10^{-4} \mathrm{M}\right)$, using a small sample volume $(\sim 0.1 \mathrm{ml})$ and light of wavelengths longer than $495 \mathrm{~nm}$, underwent a reproducible $7.5 \%$ conversion to $\left[\operatorname{Ir}\left(\mathrm{NH}_{3}\right)_{5} \mathrm{CSC}\right]^{2+}$. The photolysis of HTSC under identical conditions did not lead to any isomerization.

To obtain information on the reactivity of excited LF states of complexes of the type $\left[\mathrm{Rh}_{(}\left(\mathrm{NH}_{3}\right)_{5} \mathrm{O}_{2} \mathrm{CR}\right]^{2+}$, aqueous $\left[\mathrm{Rh}\left(\mathrm{NH}_{3}\right)_{5} \text { acetato }\right]^{2+}$ was irradiated. Upon light absorption into the first LF band $\left(\lambda_{\max }=322, \varepsilon=147\right.$ [14]), a photosubstitution of acetate with the formation of $\left[\mathrm{Rh}\left(\mathrm{NH}_{3}\right)_{5} \mathrm{H}_{2} \mathrm{O}\right]^{3+}$ (first LF band: $\left.\lambda_{\max }=315, \varepsilon=105[14]\right)$ did not take place since the photolysis did not lead to any spectral changes. The quantum yield of acetate substitution was estimated to be $\phi<5 \cdot 10^{-2}$.

\section{Discussion}

The free $\mathrm{TSC}^{-}$ligand or HTSC shows essentially the same behavior as trans-stilbene itself. Light absorption into the $\mathrm{S}_{0} \rightarrow \mathrm{S}_{1}$ band of $\mathrm{TSC}^{-}$was followed by fluorescence emission as well as trans/cis isomerization. It is generally assumed that isomerization induced by direct photolysis occurs from the first excited singlet although the lower-lying triplet is also able to lead to the isomerization as has been shown by sensitization experiments [9]. Upon continued direct photolysis of $\mathrm{TSC}^{-}$, a photostationary equilibrium between $\mathrm{TSC}^{-}$and $\mathrm{CSC}^{-}$was established since $\mathrm{CSC}^{-}$also underwent photoisomerization, $\mathrm{CSC}^{-}$, as has been shown for other cis-stilbenes, does not fluoresce. The isomerization from the first excited singlet of cis stilbenes is apparently a very rapid process.

Upon $\mathrm{S}_{0} \rightarrow \mathrm{S}_{1}$ excitation of the $\mathrm{TSC}^{-}$ligand of the complex $\left[\mathrm{M}\left(\mathrm{NH}_{3}\right)_{5} \mathrm{TSC}\right]^{2+}(\mathrm{M}=\mathrm{Rh}$ and $\mathrm{Ir})$, the isomerization of the ligand took place. However, the fluorescence was completely quenched. This observation shows that an additional deactivation path is available to the first excited singlet of the coordinated ligand. If the isomerization would still start from the $S_{1}$ state, an efficient reduction of the isomerization quantum yield is expected. Since, however, at least in the case of the iridium complex, the quantum yield is only slightly reduced compared to that of the free $\mathrm{TSC}^{-}$, the isomerization should be initiated by another lower-lying excited IL state. It is concluded that the photoactive state is the lowest triplet of the coordinated $\mathrm{TSC}^{-}$ligand. It follows that in the metal complexes the $S_{1} \rightarrow T_{1}$ intersystem crossing in the ligand is strongly enhanced. This assumption is not surprising since it is well known that the metals of the second and third transition row have much stronger spin-orbit coupling and can induce intersystem crossing in ligands by the heavy atom effect. This has been shown for metalloporphyrins [15]. When porphyrins are coordinated to second and third row transition metals the fluorescence of the porphyrin ligand is completely quenched while the phosphorescence is enhanced provided the lowest porphyrin triplet is the lowest excited state of the metalloporphyrin. Since stilbenes do not phosphoresce, the fluorescence quenching and the occurance of trans/cis isomerization is diagnostic for the triplet mechanism in the case of $\mathrm{Rh}$ and Ir complexes.

Increased intersystem crossing not only leads to an efficient population of the lowest triplet, but it also enhances the triplet deactivation to the singlet ground state. However, the relatively high quantum yield of isomerization in $\left[\operatorname{Ir}\left(\mathrm{NH}_{3}\right)_{5} \mathrm{TSC}\right]^{2+}$ shows that the isomerization from the lowest $\mathrm{TSC}^{-}$triplet is fast enough to compete with intersystem crossing to the ground state. The heavy atom effect of Ir should also increase the intensity of $\mathrm{S}_{0} \rightarrow \mathrm{T}_{1}$ absorption of the $\mathrm{TSC}^{-}$ligand. Although no new band could be identified in the long wavelength region, indirect evidence for the existence of such a band was obtained. Upon prolonged irradiation of $\left[\operatorname{Ir}\left(\mathrm{NH}_{3}\right)_{5} \mathrm{TSC}\right]^{2+}$ with light of wavelengths, longer than $500 \mathrm{~nm}$, a slow trans to cis isomerization took place. The photolysis of HTSC 
under identical conditions did not lead to any isomerization. This observation suggests that the isomerization of $\left[\operatorname{Ir}\left(\mathrm{NH}_{3}\right)_{5} \mathrm{TSC}\right]^{2+}$ was initiated by the triplet of the $\mathrm{TSC}^{-}$ ligand which was directly excited by absorption into the $S_{0} \rightarrow T_{1}$ band. Even when this band is not intense enough to be identified in the spectrum, some light can be absorbed and induce the photolysis.

The significant reduction of the isomerization quantum yield of $\left[\mathrm{Rh}\left(\mathrm{NH}_{3}\right)_{5} \mathrm{TSC}\right]^{2+}$ compared to the Ir complex requires an explanation. When the energy of the lowest excited LF state is lower than that of the first excited singlet of the ligand, but above the lowest triplet of the ligand, the deactivation of the first IL singlet to the triplet may include the intermediate population of the LF excited state. However, this LF state should not only undergo a radiationless transition to the lowest IL triplet but may also be deactivated by other processes such as ligand substitutions. Consequently the quantum yield of population of the IL triplet should be reduced. Such a mechanism has been shown to apply to some porphyrin [16] and corrin [17] complexes as well as to phenanthroline complexes of $\operatorname{Ir}(\mathrm{III})$ [18]. Unfortunately, it is difficult to verify such a mechanism for $\left[\mathrm{Rh}\left(\mathrm{NH}_{3}\right)_{5} \mathrm{TSC}\right]^{2+}$ since the IL excitation does not lead to a photosubstitution. However, the absence of any photosubstitution can not be taken as evidence against the assumption that the reduction

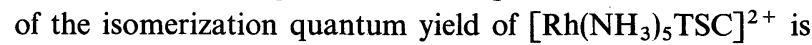
caused by the intermediate population of a $\mathrm{LF}$ state. Although LF excitation of aqueous $\left[\mathrm{Rh}\left(\mathrm{NH}_{3}\right)_{5} \mathrm{H}_{2} \mathrm{O}\right]^{3+}$ leads to an efficient exchange of the $\mathrm{H}_{2} \mathrm{O}$ ligand with solvent water [19] the quantum yield of acetate aquation is very low for $\left[\mathrm{Rh}\left(\mathrm{NH}_{3}\right)_{5} \text { acetato }\right]^{2+}$. It has been suggested that in complexes of this type the carboxylate ligand can form hydrogen bonds to the ammonia ligands [17]. These hydrogen bonds may effectively reduce substitution quantum yields by facilitating recombinations.

Although experimental evidence for the population of a LF state following IL excitation of $\left[\mathrm{Rh}\left(\mathrm{NH}_{3}\right)_{5} \mathrm{TSC}\right]^{2+}$ is missing, a rough calculation shows that the lowest $\mathrm{LF}$ triplet can indeed be placed between the first excited singlet and the lowest triplet of the $\mathrm{TSC}^{-}$ligand.

The following approximations have been used to estimate these energies. The lowest triplet of trans stilbene occurs around $17000 \mathrm{~cm}^{-1}$ [9]. Since the maximum of $S_{0} \rightarrow S_{1}$ absorption $\left(31347 \mathrm{~cm}^{-1}\right)$ and the corresponding fluorescence emission $\left(25000 \mathrm{~cm}^{-1}\right)$ of HTSC or TSC ${ }^{-}$is shifted to lower energies compared to trans stilbene $\left(\bar{v}_{\mathrm{ab}}=33300 \mathrm{~cm}^{-1}\right.$ and $\bar{v}_{\mathrm{f} 1}=27777 \mathrm{~cm}^{-1}$ ) it is reasonable to assume that the lowest $\mathrm{TSC}^{-}$triplet occurs below $17000 \mathrm{~cm}^{-1}$. The spectrum of $\left[\mathrm{Rh}\left(\mathrm{NH}_{3}\right)_{5} \mathrm{TSC}\right]^{2+}$ does not exhibit LF bands which must be hidden under the intense IL bands. However, the LF strength of carboxylate ligands $\mathrm{RCO}_{2}^{-}$is almost independent of the group $\mathrm{R}$ [7]. The energy of the lowest LF triplet of $\left[\mathrm{Rh}\left(\mathrm{NH}_{3}\right)_{5} \mathrm{O}_{2} \mathrm{CR}\right]^{2+}$ complexes can thus be estimated according to a published procedure to be approximately $21500 \mathrm{~cm}^{-1}$ [20]. This energy places the lowest LF triplet clearly between the first excited singlet and triplet of the
$\mathrm{TSC}^{-}$ligand. Although the energy of the LF states of $\left[\operatorname{Ir}\left(\mathrm{NH}_{3}\right)_{5} \mathrm{TSC}\right]^{2+}$ are not known, they certainly occur at much higher energies than those of the corresponding $\mathrm{Rh}$ complexes [21]. Hence the lowest LF triplet of the Ir complex may be well above the $\mathrm{S}_{1}$ state of $\mathrm{TSC}^{-}$. It follows that the IL excitation of $\left[\operatorname{Ir}\left(\mathrm{NH}_{3}\right)_{5} \mathrm{TSC}\right]^{2+}$ does not lead to an intermediate population of a LF state in accordance with the high isomerization quantum yield.

The quantum yields of isomerization in the opposite direction from $\mathrm{CSC}^{-}$to $\mathrm{TSC}^{-}$do not differ very much for the $\mathrm{CSC}^{-}$ ligand in the free state and in both complexes. The isomerization from the $S_{1}$ state of cis-stilbenes is assumed to be a very rapid process [9]. Also in the metal complexes the increased rate of intersystem crossing can apparently not compete with the isomerization from the first excited singlet of the coordinated $\mathrm{CSC}^{-}$ligand.

Financial support for this research by the Deutsche Forschungsgemeinschaft and the Fonds der Chemischen Industrie is gratefully acknowledged.

\section{References}

[1] M. S. Wrighton, Topics in Current Chemistry 65, 79 (1976).

[2] A. Vogler, Concepts of Inorganic Photochemistry, p. 292, A. W. Adamson and P. D. Fleischauer, eds., Wiley 1975.

[3] M. Wrighton, G. S. Hammond, and H. B. Gray, Mol. Photochem. 5, 179 (1973).

[4] M. S. Wrighton, D. L. Morse, and L. Pdungsap. J. Am. Chem. Soc. 97, 2073 (1975).

[5] P. P. Zarnegar, C. R. Bock, and D. G. Whitten, J. Am. Chem. Soc. 95, 4367 (1973).

[6] M. Wrighton, G. S. Hammond, and H. B. Gray, J. Am. Chem. Soc. 93, 3285 (1971).

[7] A. W. Adamson, A. Vogler, and I. Lantzke, J. Phys. Chem. 73, 4183 (1969).

[8] P. C. Ford, R. E. Hintzke, and J. D. Petersen, Concepts of Inorganic Photochemistry, chap. 5, A. W. Adamson and P. D. Fleischauer, eds., Wiley 1975.

[9] J. Saltiel, J. D’Agostino, E. D. Megarity, L. Metts, K. R. Neuberger, M. Wrighton, and O. C. Zafiriou, Organic Photochemistry, Vol. 3, chap. 1, Marcel Dekker, New York 1973.

[10] F. Bell and D. H. Waring, J. Chem. Soc. 1024 (1948)

[11] G. Berti and F. Bottari, Gazz. Chim. Ital. 89, 2371 (1959).

[12] F. Monacelli, F. Basolo, and R. G. Pearson, J. Inorg. Nucl. Chem. 24, 1241 (1962).

[13] R. Benson and D. F. Williams, J. Phys. Chem. 81, 215 (1977).

[14] H.-H. Schmidtke, Z. Phys. Chem. NF 45, 305 (1965).

[15] D. L. Eastwood and M. Gouterman, J. Mol. Spectrosc. 35, 359 (1970).

[16] A. Vogler and H. Kunkely, Ber. Bunsenges. Phys. Chem. 80, 425 (1976).

[17] A. Vogler, R. Hirschmann, H. Otto, and H. Kunkely, Ber. Bunsenges. Phys. Chem. 80, 420 (1976).

[18] R. Ballardini, G. Varani, L. Moggi, V. Balzani, K. R. Olson, F. Scandola, and M. Z. Hoffman, J. Am. Chem. Soc. 97, 728 (1975).

[19] P. C. Ford and J. D. Petersen, Inorg. Chem. 14, 1404 (1975).

[20] P. E. Hoggard and H.-H. Schmidtke, Ber. Bunsenges. Phys. Chem. 77, 1052 (1973).

[21] A. Wölpl and D. Oelkrug, Ber. Bunsenges. Phys. Chem. 79, 394 (1975).

(Eingegangen am 13. November 1978,

E 4203 endgültige Fassung am 31. Januar 1979) 